\title{
KEPOTAJWID: APLIKASI PEMBELAJARAN ILMU TAJWID BERBASIS WEB INTERAKTIF
}

\author{
Viska Mutiawani \\ Fakultas MIPA, Jurusan Informatika \\ Universitas Syiah Kuala \\ Email: viska.mw@unsyiah.ac.id
}

\section{Maria Ulfa, Muslim}

Fakultas MIPA, Jurusan Informatika, Program Studi Manajemen Informatika

Universitas Syiah Kuala

maria.ulfa@s1.informatika.unsyiah.ac.id, muslim.amiren@unsyiah.ac.id

\section{Info Artikel}

\section{Kata Kunci :}

IImu tajwid, media belajar interaktif, aplikasi web

\section{Keywords :}

tajweed, interactive learning media, web application

\section{Abstrak}

IImu Tajwid adalah suatu cabang pengetahuan untuk mempelajari cara-cara pembacaan Al-Qur'an. Al-Qur'an merupakan kitab suci umat beragama Islam. Hukum membaca ayat Al-Qur'an dengan Tajwid adalah fardhu'ain bagi setiap orang Islam (muslim). Namun ilmu Tajwid tergolong ilmu yang sulit khususnya bagi orang yang tidak fasih dalam berbahasa Arab. Berdasarkan hasil survei awal terhadap 31 responden yang beragama Islam, hampir semuanya setuju bahwa ilmu Tajwid merupakan ilmu yang sangat penting dipelajari oleh umat Islam sehingga media belajar yang interaktif serta diikuti dengan penjelasan dan latihan melalui video memberikan kemudahan dalam proses belajar dan meningkatkan minat belajar ilmu Tajwid. Namun referensi belajar ilmu Tajwid yang terpercaya banyak yang menggunakan bahasa Arab sehingga susah dipahami oleh muslim di Indonesia. Oleh karena itu, dibangunlah aplikasi ilmu tajwid yang diberi nama KepoTajwid. Aplikasi ini dikembangkan dengan metode RAD (Rapid Application Development) dan diuji menggunakan metode Black Box testing. Aplikasi ini terdiri dari materi dasar ilmu Tajwid yaitu hukum nun sukun dan tanwin, hukum mim sukun, makharijul huruf, shifatul huruf dalam bentuk teks, gambar, audio dan video.

\section{Abstarct}

Tajweed (elocution) is a branch of knowledge studying the ways of reading Qur'an. Qur'an is the holy book for Muslims (Islam people). The law of reading verses of the Qur'an with Tajweed is fardhu'ain for every Muslims. However Tajweed is a difficult knowledge especially for people who are not fluent in Arabic. Based on a preliminary survey results of 31 respondents who are Muslims, most respondents agree that Tajweed is a very important knowledge to be learned by Muslims so that interactive learning media which includes exercises and explanations via video will facilitate the learning process and increase interest in learning Tajweed. However many trusted Tajweed's references for learning are mostly in Arabic so it makes the learning process difficult for Muslims in Indonesia. Therefore a web-based application to learn Tajweed was developed and named KepoTajwid. This application was developed by using Rapid Application Development (RAD) method and then tested by using Black Box testing method. This application consists of explanation texts, images, audios and videos that explain basic Tajweed materials namely law of nun sukun and tanwin, law of mim sukun, makharijul letters, shifatul letters. 


\section{PENDAHULUAN}

IImu tajwid adalah suatu cabang pengetahuan untuk mempelajari cara-cara pembacaan Al-Qur'an secara baik dan benar sehingga sempurna maknanya [1]. Tajwid itu sendiri maknanya ialah membetulkan dan membaguskan bunyi bacaan AlQur'an menurut aturan-aturan hukum yang tertentu. Aturan-aturan itu antara lain adalah: hukum bacaan (cara-cara membaca), makhrijul huruf (tempat-tempat keluar huruf), shifatul huruf (sifat-sifat huruf), ahkamul-huruf (hukum yang tertentu bagi tiap-tiap huruf), mad (ukuran bagi panjang dan pendeknya sesuatu bacaan), dan ahkamul-auqauf (hukumhukum bagi penentuan berhenti atau terusnya suatu bacaan) [1].

Seorang muslim harus bisa membaca ayat-ayat Al-Quran dengan baik sebagaimana yang diajarkan oleh Rasulullah SAW. Membaca Al-Quran sesuai ilmu tajwid hukumnya Fardhu'Ain atau bermakna wajib bagi setiap muslim serta tidak bisa diwakili oleh orang lain. Sehingga apabila seorang muslim membaca Al-Quran tidak sesuai dengan tajwidnya, maka ia akan berdosa karena sesungguhnya Allah SWT menurunkan Al-Quran berikut tajwidnya [2].

Pada umumnya pembelajaran ilmu tajwid sudah diajarkan sejak kecil dan dalam jangka waktu yang lama. Akan tetapi, hanya sedikit umat muslim yang memahami ilmu tajwid secara menyeluruh. Meskipun minat belajar ilmu tajwid masih ada, namun banyak dari umat muslim yang sibuk dengan aktivitasnya sehingga tidak bisa membagi waktu untuk belajar ilmu tajwid. Maka tak jarang umat muslim memilih belajar ilmu tajwid di rumah. Namun media pembelajaran yang tersedia di rumah memiliki kekurangan seperti buku yang penyajiannya berupa tulisan sehingga susah dipahami bunyinya dan panjang pendek dari suatu bacaan tajwid. Selain itu buku ilmu tajwid yang penyajiannya dalam bahasa Arab sehingga susah dipahami oleh umat muslim awam dan bisa jadi sumber bacaan tajwidnya kurang terpercaya [3].

Kajian awal dari penelitian ini berupa pembagian kuesioner kepada 31 responden yaitu umat muslim yang dipilih secara acak. Hasil kajian awal yang dianalisis menggunakan analis frekuensi (proporsi) menunjukkan bahwa $97 \%$ responden setuju bahwa ilmu tajwid adalah ilmu yang sangat penting dipelajari oleh setiap umat Islam. Selain itu responden setuju bahwa kesulitan belajar ilmu tajwid juga disebabkan oleh media belajar ilmu tajwid yang terpercaya dan detail biasanya menggunakan bahasa Arab sehingga umat muslim awam kesulitan memahaminya.

Pemanfaatan media dalam proses pembelajaran memegang peranan penting dalam proses belajar. Media pembelajaran ini berisi materi-materi yang tujuannya dapat memudahkan pengguna untuk memahami materi yang disajikan. Menurut Paradesa [4], pemilihan materi yang sesuai dengan media pembelajaran merupakan langkah awal yang penting. Berdasarkan hasil kajian awal, responden setuju bahwa solusi dari permasalahan kesulitan belajar ilmu tajwid adalah dengan dikembangkannya sebuah media pembelajaran interaktif dalam bahasa Indonesia yang di dalamnya terdapat materi pembelajaran diikuti dengan latihan dan penjelasan melalui video. Selain itu responden sangat setuju bahwa belajar melalui media yang interaktif dapat mendukung minat belajar.

Media pembelajaran interaktif dapat disajikan dalam bentuk situs web. Situs web merupakan kumpulan halaman web terkait termasuk konten multimedia. Situs web dapat diakses dengan menggunakan browserpada sistem operasi apapun baik pada komputer, tablet maupun smartphone. Situs web merupakan hasil dari perkembangan teknologi informasi yang penggunaannya semakin luas, salah satunya sebagai media pembelajaran. Penggunaan media ini dapat menunjang proses pembelajaran peserta didik dimana dan kapan saja. Situs web memberikan keunggulan dalam menyediakan informasi secara cepat dan mudah. Selain itu situs web dapat mengandung konten multimedia yang dapat membuat belajar lebih menarik, ilustratif dan interaktif [5]. Situs web dapat dibangun menggunakan sebuah frameworktertentu. Codelgniter adalah salah satu framework yang dapat digunakan untuk membuat aplikasi berbasis web yang disusun dengan menggunakan bahasa PHP. Dengan berbagai keunggulan yang ditawarkan oleh Codelgniter dapat menjadikan media pembelajaran ini lebih mudah dalam pengelolaannya [6]. Oleh sebab itu, penelitian ini akan menghasilkan aplikasi pembelajaran ilmu tajwid berbasis web interaktif. Materi yang disajikan pada aplikasi ini dikhususkan pada aturan-aturan hukum dasar ilmu tajwid seperti: hukum bacaan nun bersukun dan tanwin, hukum bacaan mim mati, makharijul huruf (tempat-tempat keluar huruf) dan shifatul huruf(sifat- sifat huruf).

\section{TINJAUAN PUSTAKA}

\subsection{IImu Tajwid}

Kata tajwid berasal dari bahasa Arab yaitu jawwada - yujawwidu yang berarti “membaguskan”. Jadi tajwid bermakna membaguskan bacaan huruf atau kalimat Al-Qur'an satu per satu dengan terang, teratur, perlahan dan tidak terburu-buru sesuai dengan kaidah-kaidah ilmu tajwid [1]s. IImu tajwid secara istilah merupakan ilmu yang berguna untuk mengetahui bagaimana cara memenuhkan/memberikan haq huruf dan mustahaqnya [7]. Baik yang berkaitan dengan sifat huruf, bacaan mad dan sebagainya. Yang dimaksud dengan haq huruf adalah sifat asli yang selalu bersama, seperti sifat al-hams, al- jahr, asy-syiddah dan lain sebagainya. Sedangkan yang dimaksud dengan mustahaq hurufadalah sifat yang tampak pada kondisi dan waktu-waktu tertentu seperti tafkhim, tarqiq, ikhfa' dan lain sebagainya. Tajwid merupakan bentuk masdhar dari fi'il 
madhiyang berarti membaguskan, menyempurnakan, memantapkan. Tujuan mempelajari ilmu tajwid adalah untuk menjaga lidah dari kesalahan di saat membaca Al-Qur'an [7].

Mempelajari ilmu tajwid hukumnya adalah Fardhu Kifayah, namun mempergunakan ilmu tajwid dalam membaca AlQur'an adalah Fardhu 'Ain [1]. IImu tajwid bukanlah sekadar teori namun haruslah dipraktikkan. Banyak orang yang berpikir, sekadar bisa membaca Al-Qur'an sudah cukup. Sehingga, ramai orang yang bisa membaca Al-Qur'an, namun banyak kesalahannya dari sisi tajwid [7]. Materi yang disajikan pada aplikasi ini dikhususkan pada aturan-aturan hukum dasar ilmu tajwid seperti: hukum bacaan nun bersukun dan tanwin, hukum bacaan mim mati, makharijul huruf (tempat-tempat keluar huruf) dan shifatul huruf(sifat- sifat huruf).

Nun bersukun dikenal dengan sebutan lain yaitu "nun mati". Tanwin menurut bahasa adalah suara seperti kicauan burung. Terdapat perbedaan utama antara nun bersukun dan tanwin yaitu: nun bersukun tetap nyata dalam penulisan maupun pengucapan, baik ketika washa/maupun waqaf. Sedangkan tanwin tetap nyata (terdengar) dalam pengucapan dan ketika washal, tidak dalam penulisan maupun waqaf [7]. Terdapat empat hukum nun bersukun dan tanwin ketika menghadapi huruf hijaiyah. Empat hukum tersebut ialah izhar halqi, idgham (idgham bighunnah dan idgham bilaghunnah), iqlab, ikhfa.

Aturan berikutnya adalah mim mati. Mim mati adalah huruf mim yang bertanda sukun. Terdapat tiga hukum mim mati ketika menghadapi huruf hijaiyah yaitu ikhfa syafawi, idgham mimi, izhar syafawi.

Aturan hukum dasar berikutnya yang akan dimasukkan ke dalam aplikasi adalah makharijul huruf. Makharijul huruf adalah tempat-tempat keluarnya huruf. Semua huruf mempunyai tempat asal yang dikeluarkan sehingga membentuk bunyi tertentu. Jadi makharijul huruf adalah tempat keluarnya huruf pada waktu huruf tersebut dibunyikan. Jika huruf itu tidak dikeluarkan dari tempat asalnya, maka bunyinya menjadi tidak tepat, serta tidak dapat dibedakan huruf satu dengan yang lainnya [8].

Berikutnya shifatul huruf menurut bahasa adalah apa-apa yang ada pada suatu huruf yang dapat memberi makna dan apa-apa yang menyerupainya. Sedangkan pengertian menurut istilah adalah sifat yang tampak saat huruf itu keluar dari makhrajyya yaitu: jelas, lunak dan lain sebagainya [7]. Sifat-sifat huruf dalam Al-Qur'an terbagi menjadi dua, yaitu:

1. Sifat yang memiliki lawan, seperti:

- Al-Hamslawannya Al-Jahr

- Ar-Rakhawahlawannya As-Syiddah dan At-Tawassuth

- Al-Istilalawannya Al-Istifal

- Al-Infitah lawannya Al-Ithbaq'

- Al-Ishmat lawannya Al-Izlaq

2. Sifat yang tidak memiliki lawan, seperti:

- As-Shafir

- Al-Qalqalah

- Al-Lain

- Al-Inhiraf

- At-Takrir

- At-Tafasyi

- Al-lstithalah

\subsection{Situs Web Interaktif}

Aplikasi ilmu tajwid yang dikembangkan berbasis web. Sebab situs web dapat menyediakan informasi serta fasilitas multimedia yang dapat membuat belajar lebih menarik, ilustratif dan interaktif [5]. Multimedia merupakan kombinasi teks, gambar, animasi, suara dan video yang berupa format digital dan disampaikan oleh komputer atau peralatan elektronik lainnya. Jika pengguna multimedia dapat mengontrol apa dan kapan elemen-elemen tersebut akan dikirimkan, multimedia disebut multimedia interaktif [9]. Situs web merupakan salah satu pengaplikasian multimedia berbasis komputer. Situs web menjadi interaktif ketika terdapat hubungan timbal balik antara pengguna dan sistem di dalamnya.

Aplikasi yang memiliki konten multimedia dipilih sebab perpaduan antara indra penglihatan dan pendengaran terbukti mampu membuat orang mengingat $80 \%$ dari apa yang dilihat dan didengar sekaligus, sesuai hasil dari lembaga riset penerbitan komputer yaitu Computer Technology Research (CTR). Namun, orang hanya mampu mengingat $20 \%$ dari apa yang dilihat dan hanya mampu mengingat $30 \%$ dari apa yang didengar [10].

\subsection{Rapid Application Development}

Proses pengembangan sebuah aplikasi memerlukan metode pengembangan agar dapat menghasilkan aplikasi yang sesuai dengan kebutuhan pengguna. Salah satu metode pengembangan aplikasi adalah RAD (Rapid Application 
Development). RAD memiliki siklus pengembangan yang relatif singkat. Metode RAD mementingkan keterlibatan pengguna dalam proses analisis dan perancangannya, dengan harapan dapat memenuhi kebutuhan pengguna dengan baik sehingga dapat meningkatkan tingkat kepuasan pengguna sistem [11].

Menurut Kendall \& Kendall [12], terdapat tiga fase dalam RAD yang melibatkan penganalisis dan pengguna dalam tahap penilaian, perancangan, dan penerapan, yaitu : requirements planning (perencanaan keperluan/ kebutuhan), RAD design workshop (workshop perancangan RAD), dan implementation (implementasi).

Fase perencanaan keperluan melibatkan pengguna dan penganalisis berdiskusi untuk mengidentifikasikan tujuan aplikasi atau sistem serta syarat-syarat informasi yang dibutuhkan dari tujuan-tujuan tersebut. Fase ini akan mendefinisikan cara menyelesaikan masalah-masalah pada pelanggan, institusi atau perusahaan. Sehingga fokus atau tujuan dari aplikasi atau sistem yang dibangun akan tercapai [12].

Fase workshop perancangan RAD melibatkan penganalisis dan pemrogram untuk merancang dan memperbaiki rancangan aplikasi atau sistem yang akan dikembangkan. Penganalisis dan pemrogram bekerja membangunkan dan menunjukkan representasi rancangan visual dan pola kerja kepada pengguna. Kemudian pengguna merespon prototipe yang telah dibuat dan penganalisis memperbaiki aplikasi atau sistem yang dirancang berdasarkan respon pengguna. Fase ini dapat dilakukan selama beberapa hari tergantung dari ukuran aplikasi atau sistem yang akan dikembangkan [12].

Pada fase implementasi, penganalisis bekerja dengan para pengguna dalam merancang aspek-aspek bisnis dan nonteknis dari institusi atau perusahaan. Setelah aspek-aspek ini disetujui, maka aplikasi atau sistem akan dibangunkan dan diujicoba. Jika proses ujicoba berhasil maka aplikasi atau sistem akan diperkenalkan kepada instansi, perusahaan atau masyarakat umum yang bersangkutan [12].

\subsection{Metode Pengujian Black Box}

Pengujian perangkat lunak sangat diperlukan dalam suatu sistem informasi atau aplikasi. Proses pengujian akan berusaha menemukan kesalahan atau erroryang muncul dari suatu sistem perangkat lunak. Sehingga pemprogram akan bisa mengetahui apa yang harus diperbaiki dan dikerjakan selanjutnya. Pengujian perangkat lunak sangat penting dilakukan untuk menentukan kualitas perangkat lunak [13]. Pengujian melibatkan sederetan aktivitas yang hasilnya dapat menjamin kualitas dari produk sebab pada pengujian akan diukur semua karakteristik spesifikasi, yang telah ditentukan pada fase pengembangan perangkat lunak, apakah memenuhi harapan pengguna atau tidak.

Banyak metode pengujian perangkat lunak, salah satu diantaranya adalah pengujian Black Box (kotak hitam). Metode pengujian Black Box dilakukan berdasarkan pada analisis spesifikasi perangkat lunak tanpa melihat pada kerja internalnya. Tujuannya adalah untuk menguji seberapa baik komponen sesuai dengan persyaratan/spesifikasi yang didefinisikan untuk komponen tersebut. Pengujian Black Box tidak mengacu pada struktur logis internal sistem, hanya memeriksa aspek fundamental sistem yaitu dengan memastikan input diterima dengan benar dan outputnya diproduksi dengan benar pula [13].

\section{METODOLOGI PENELITIAN}

Aplikasi ini dikembangkan menggunakan metode Rapid Application Development (RAD). Penjelasan untuk setiap langkah yang dilakukan adalah berikut ini.

\subsection{Perencanaan Keperluan/Kebutuhan}

Tahapan ini berisi tujuan dari aplikasi dan identifikasi kebutuhan sistem. Tujuan dari pengembangan aplikasi ini adalah tersedianya aplikasi berbasis web interaktif sebagai media pembelajaran ilmu tajwid dalam bahasa Indonesia. Sistem ini berisi materi pembelajaran yang disajikan dalam bentuk video dan soal latihan terkait materi yang disampaikan.

\subsection{Proses Perancangan}

Perancangan yang dilakukan adalah perancangan fungsional sistem, perancangan basis data dan perancangan tampilan aplikasi. Pada perancangan fungsional sistem, aplikasi yang akan dibangun hanya membutuhkan dua aktor (pengguna) yaitu user atau pengguna dan administrator. Pengguna memiliki hak mengakses situs web secara bebas. Pengguna dapat melihat video materi dan menjawab soal berdasarkan materi yang tersedia. Selain itu, pengguna juga dapat memberikan saran untuk perbaikan aplikasi. Administrator memiliki hak manajemen materi yaitu menambah, mengubah dan menghapus materi. Hak yang dimiliki setiap aktor tersebut dapat digambarkan dengan Use Case diagram. Use Case diagram sistem dapat dilihat pada Gambar 1. 


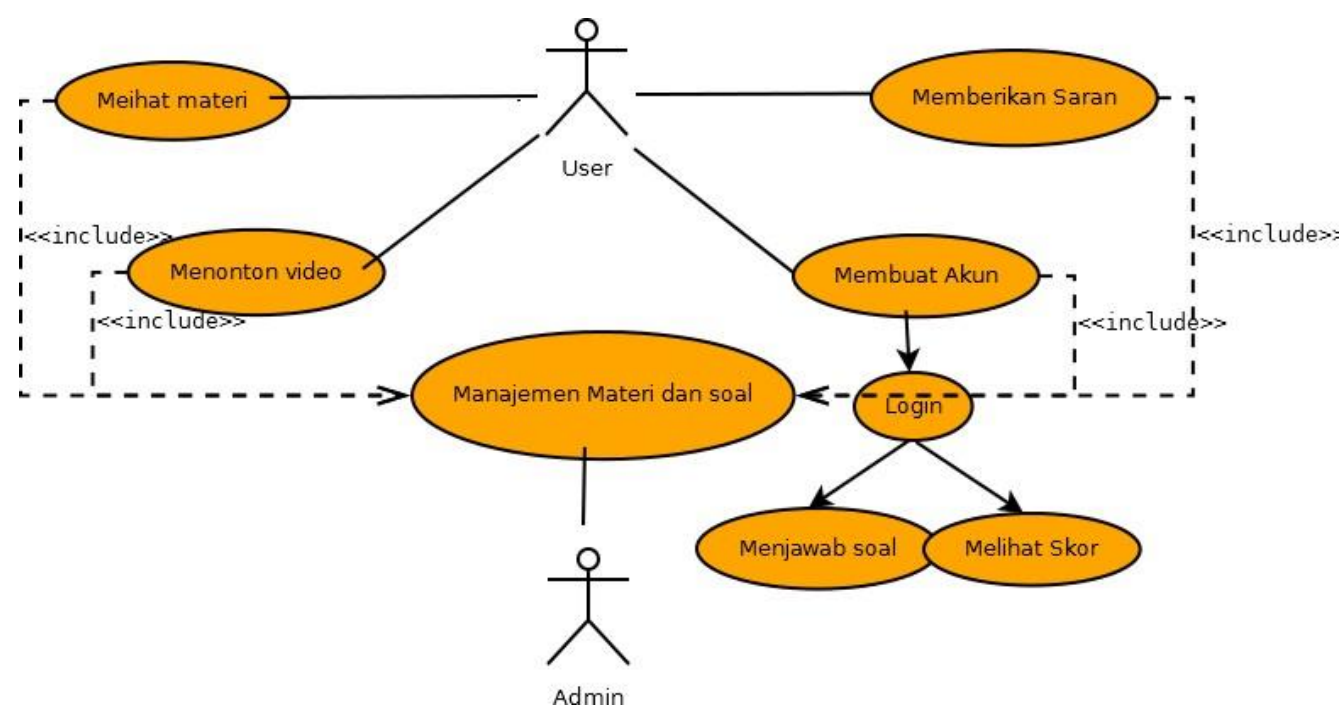

Gambar 1. Use Case Diagram

Basis data pada aplikasi ini terdiri dari tabel admin, materi, materi_kategori, materi_sub_kategori, materi_sub_sub_ kategori, pengguna, pertanyaan_hasil, pertanyaan_jawaban, pertanyaan_soal, postingan_menarik, saran dan video. Tabel materi, materi_kategori, materi_sub_kategori, dan materi_sub_sub_kategori berisi informasi mengenai konten-konten yang berkaitan dengan materi. Tabel pertanyaan_hasil, pertanyaan_jawaban, dan pertanyaan_soal berkaitan dengan soal-soal latihan dan skornya dalam menjawab soal-soal latihan. Tabel video berkaitan dengan video-video yang akan diunggah ke dalam web. Tabel pengguna berisi informasi data pengguna (username dan password). Tabel admin adalah tabel yang berisi informasi mengenai administrator yaitu username dan password. Tabel postingan_menarik berisi postingan harian yang menarik dan terus diperbaharui Tabel saran berisi saran pengguna media terkait perbaikan aplikasi kedepannya.

Rancangan tampilan aplikasi terdiri dari dua halaman utama yaitu halaman untuk pengguna dan halaman untuk administrator. Halaman pengguna merupakan halaman yang dapat digunakan dan dilihat oleh pengguna. Pada tampilan halaman awalnya terdapat menu "Beranda", "Fitur", "Galeri", "Tentang Kami”, dan "Hubungi Kami". Dan di dalam slidemya terdapat button "Gunakan Media" untuk menuju ke halaman utama media pembelajarannya. Halaman admin adalah halaman yang digunakan oleh admin untuk memasukkan data yang akan ditampilkan pada halaman pengguna. Halaman admin hanya dapat digunakan oleh admin dengan cara melakukan login terlebih dahulu. Halaman utama admin terdiri dari 4 menu utama yaitu "Postingan Menarik", "Materi”, "Video Lain", dan "Latihan". Setiap menu utama tersebut akan menyediakan fasilitas insert, delete, dan update.

\subsection{Implementasi}

Setelah proses perancangan sistem diselesaikan, tahapan selanjutnya yang dilakukan adalah coding yaitu proses penggunaan bahasa pemrograman dalam membangun aplikasi yang sudah dirancang sebelumnya. Proses membangun aplikasi pada tahapan ini masih berupa prototipe saja. Bahasa pemrograman utama yang digunakan adalah PHP dan Javascript dengan memanfaatkan framework Codelgniter. Selain itu untuk menambahkan interaktivitas, aplikasi juga menggunakan teknologi AJAX (Asynchronous JavaScript And XML) dan libraryjQuery.

Setelah proses implementasi dalam bentuk coding selesai dikerjakan dan pengguna telah setuju dengan semua rancangan dan modul, tahapan selanjutnya yang dilakukan adalah proses pengujian sistem. Tahapan ini diperlukan untuk mengetahui sistem telah berjalan dengan baik atau tidak. Pengujian sistem ini dilakukan menggunakan metode Black Box.

\section{HASIL DAN PEMBAHASAN}

Aplikasi yang dihasilkan diberi nama KepoTajwid. Pemilihan nama tersebut dengan tujuan agar masyarakat umum tertarik untuk mendalami ilmu tajwid sehingga bisa membaca Al-Qur'an dengan baik dan benar. Aplikasi ini terdiri dari beberapa materi yang terbagi menjadi beberapa kategori, sub kategori dan sub sub kategori. Aplikasi ini menyediakan latihan bagi pengguna untuk setiap kategori. Setiap materi baik sub materi kategori atau sub sub materi kategori disajikan dalam bentuk teks, gambar, dan audio atau video yang diakses melalui YouTube. Pemanfaatan YouTube dilakukan untuk 
menghemat resources server. Implementasi dari rancangan basis data menghasilkan 12 tabel. Gambaran tabel-tabel tersebut dapat dilihat pada Gambar 2.

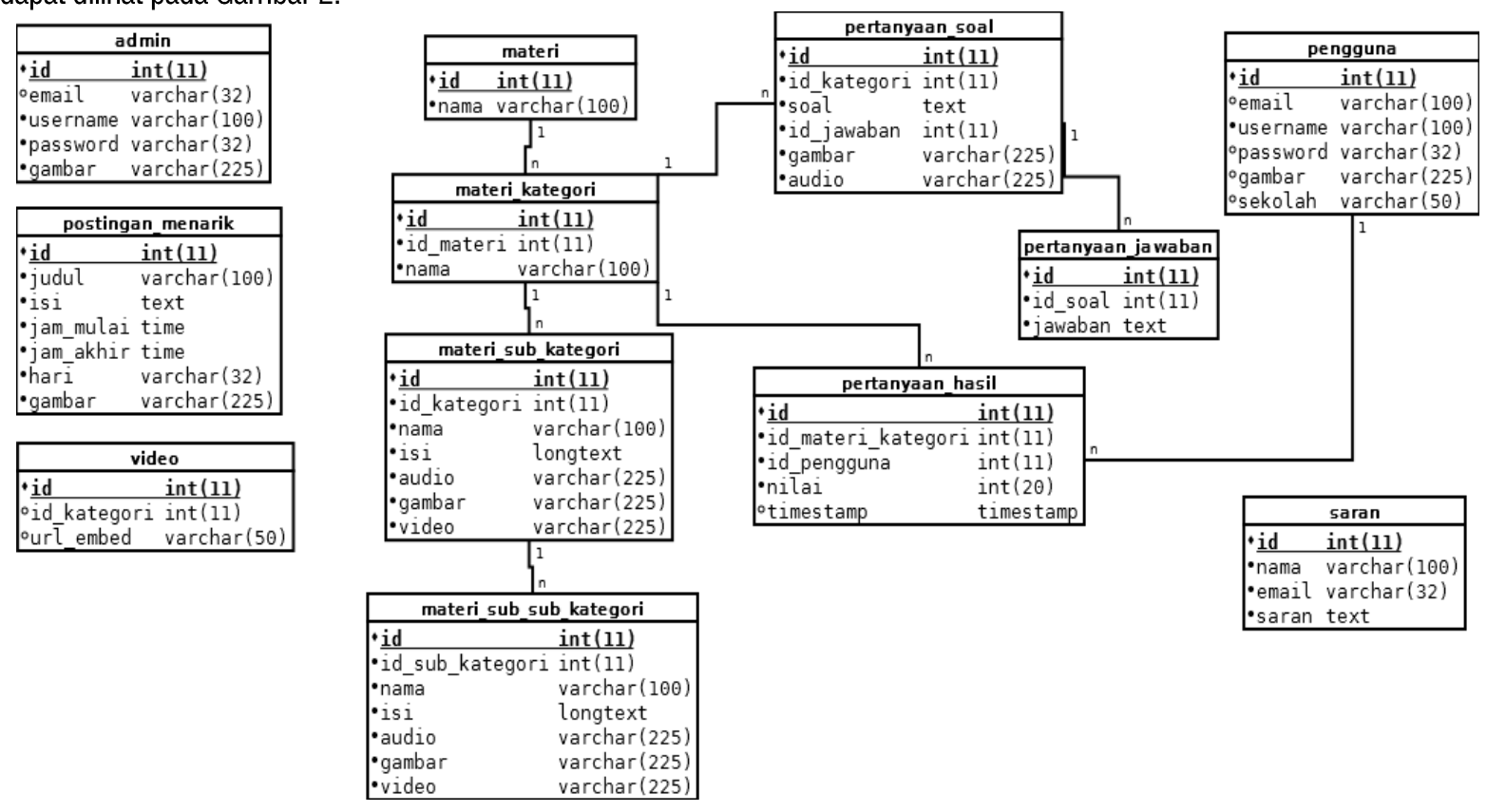

Gambar 2. Implementasi Tabel di dalam Basis Data

Aplikasi ini disusun secara bertahap mulai dari materi yang mudah hingga sulit sehingga memudahkan pengguna dalam mempelajarinya. Adanya audio dan video dalam materi dimaksudkan dapat menunjang pemahaman dari pengguna. Audio dan video dapat diputar berulang kali tergantung tingkat pemahaman pengguna dalam mempelajarinya. Pengguna dapat menjawab soal latihan yang telah disediakan sebagai fasilitas untuk melihat tingkat pemahaman materi. Aplikasi ini hanya terdiri dari dua aktor yaitu pengguna dan administrator. Pengguna dapat mengakses materi dengan memutar audio, melihat video, dan mengerjakan latihan.

Pengguna juga diberikan akses menu khusus "video" yang disediakan untuk menambah pengetahuan berkaitan dengan ilmu tajwid. Selain itu, pengguna juga difasilitasi menu untuk menghubungi admin dan memberikan saran serta masukan kepada admin sehingga dapat melakukan perbaikan terhadap aplikasi. Aplikasi ini juga menyediakan menu "postingan menarik" yakni postingan-postingan menarik seputar agama Islam untuk menambah wawasan pengguna. Administrator dapat menambah, mengubah dan menghapus konten materi, dan soal latihan. Selain itu, administrator juga dapat menambah, mengubah dan menghapus konten postingan menarik, video tertentu serta melihat dan menghapus saran / masukan dari pengguna.

Halaman yang disajikan bagi Pengguna terdiri dari beberapa halaman, diantaranya: halaman awal, halaman postingan menarik, halaman materi, halaman latihan, dan halaman video lain. Pada halaman awal aplikasi menampilkan beberapa informasi tentang KepoTajwid sebelum memulai menggunakan media pembelajaran. Informasi yang dimaksud antara lain: penjelasan aplikasi KepoTajwid, sumber rujukan materi pembelajaran, dan beberapa orang yang terlibat dalam pengembangan KepoTajwid. Dari halaman awal, pengguna dapat memilih tombol "Gunakan Media" maka akan menuju ke halaman utama. Halaman utama yang dimaksud adalah halaman Postingan Menarik seperti pada Gambar 3. 


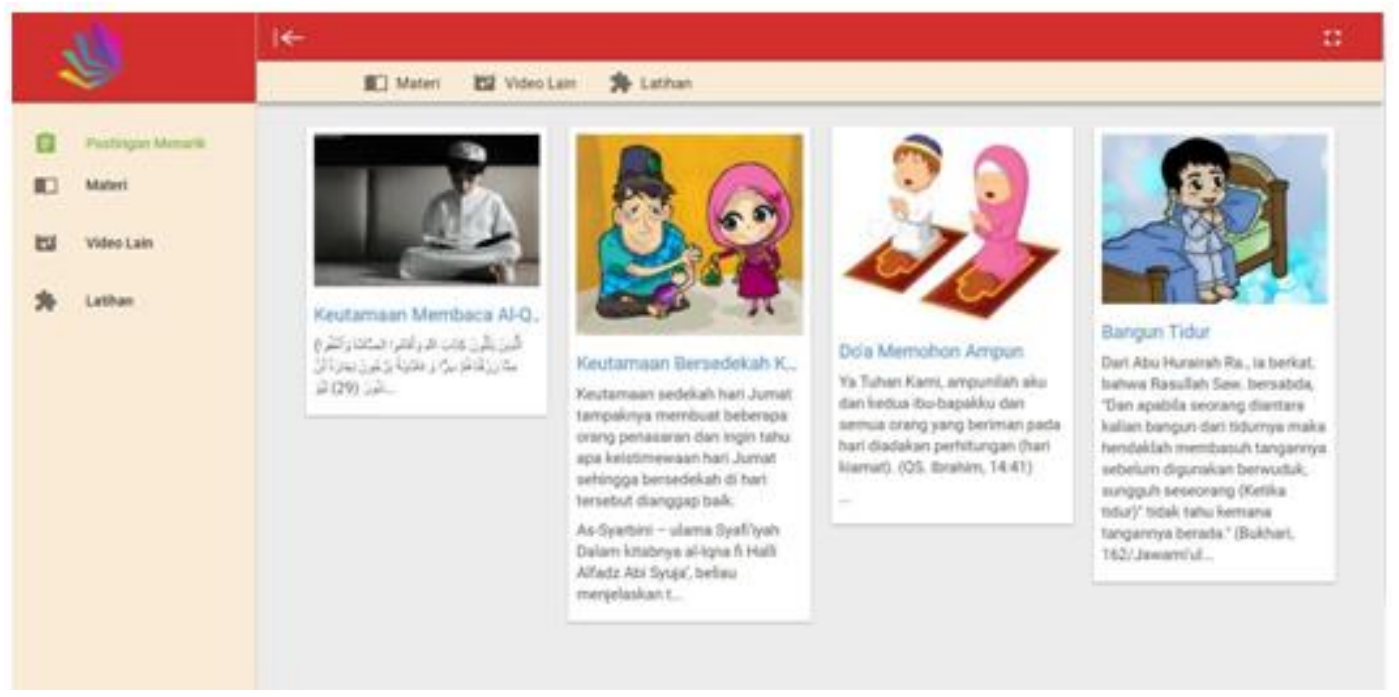

Gambar 3. Tampilan Halaman Utama Aplikasi

Pada halaman utama menampilkan menu-menu utama yang disajkan pada aplikasi KepoTajwid. Menu tersebut adalah menu Postingan Menarik itu sendiri, Materi, Video Lain dan Latihan. Sedangkan di sisi atas terdapat menu yang sama kecuali menu Postingan Menarik. Menu di sisi atas dibuat untuk mengatasi jika media yang digunakan dalam membuka aplikasi berukuran kecil. Sehingga sisi kanan atau selanjutnya kita sebut sidebar bisa disembunyikan. Tampilan seperti ini untuk mempermudah aplikasi dibuka di perangkat kecil seperti smartphone dan tablet. Icon KepoTajwid yang berada di sisi atas dari sidebaruntuk menu kembali ke halaman awal. Seperti penjelasan sebelumnya, aplikasi KepoTajwid mengelompokkan Materi, Video Lain, dan Latihan dalam beberapa kategori. Ketika menu utama tersebut dipilih maka halaman yang ditampilkan seperti Gambar 4 yaitu halaman materi.

Halaman materi menampilkan materi pembelajaran ilmu tajwid. Pengguna dapat memilih materi apa yang ingin dijelajahi berdasarkan kategori. Pada halaman yang dipilih pengguna disuguhkan halaman yang berisi materi_sub_kategori dan materi_sub_sub_kategori. Ketika materi_sub_sub_kategori dipilih maka akan terdapat sub materi lainnya. Selanjutnya tampilan yang terlihat adalah halaman materi pembelajaran ilmu tajwid seperti Gambar 5. Halaman tersebut berisi gambar, audio (gambar audio), teks dan video. Gambar, audio dan video merupakan hasil rekaman oleh peneliti yang melibatkan ustadz yang berkompeten dalam bidang ilmu Tajwid. Sedangkan teks penjelasan ilmu tajwid juga berasal dari sumber terpercaya yaitu kitab tajwid musawwir karangan Syekh Aiman Rusydi Suwaid.

Selain menu materi, aplikasi KepoTajwid juga terdapat menu Video Lain. Menu tersebut berisi video-video yang berkaitan dengan materi pembelajaran yang telah disaring dan dikelompokkan berdasarkan materi pembelajaran ilmu tajwid. Contoh tampilan halaman tersebut dapat dilihat pada Gambar 6.

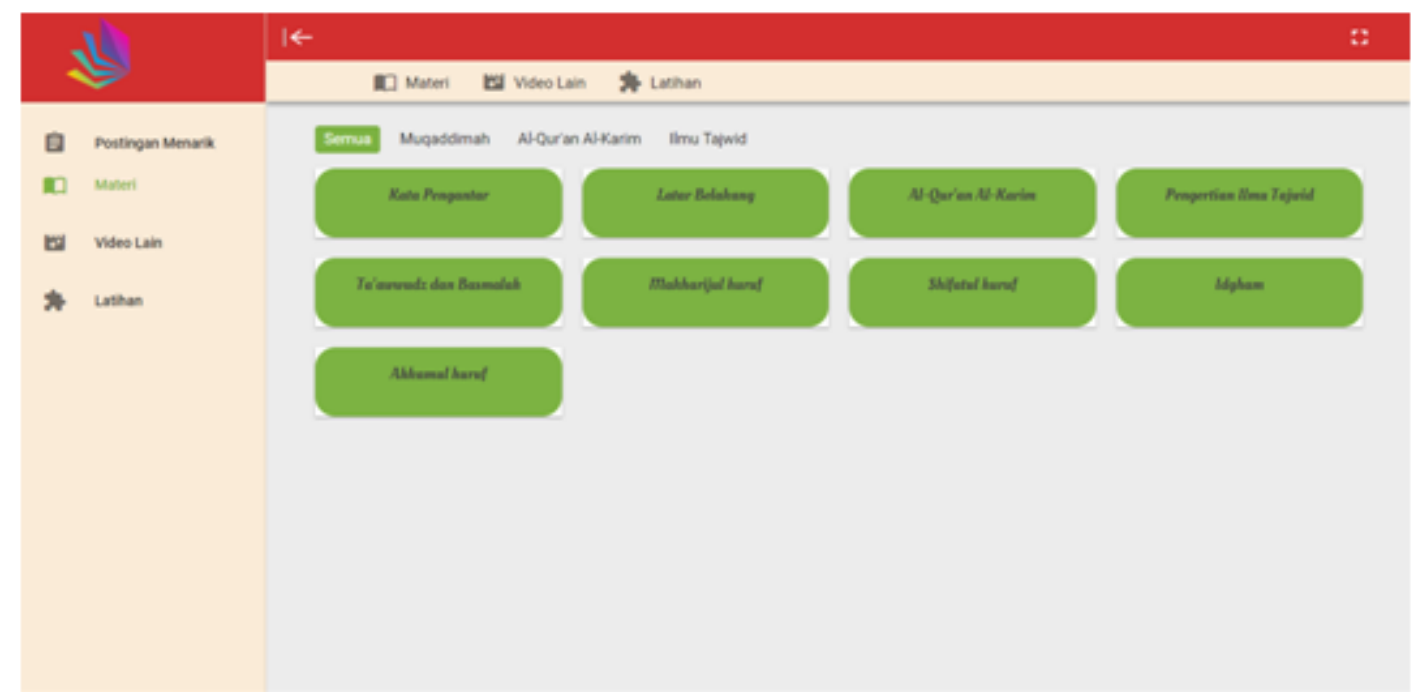

Gambar 4. Tampilan Halaman Kategori Materi 


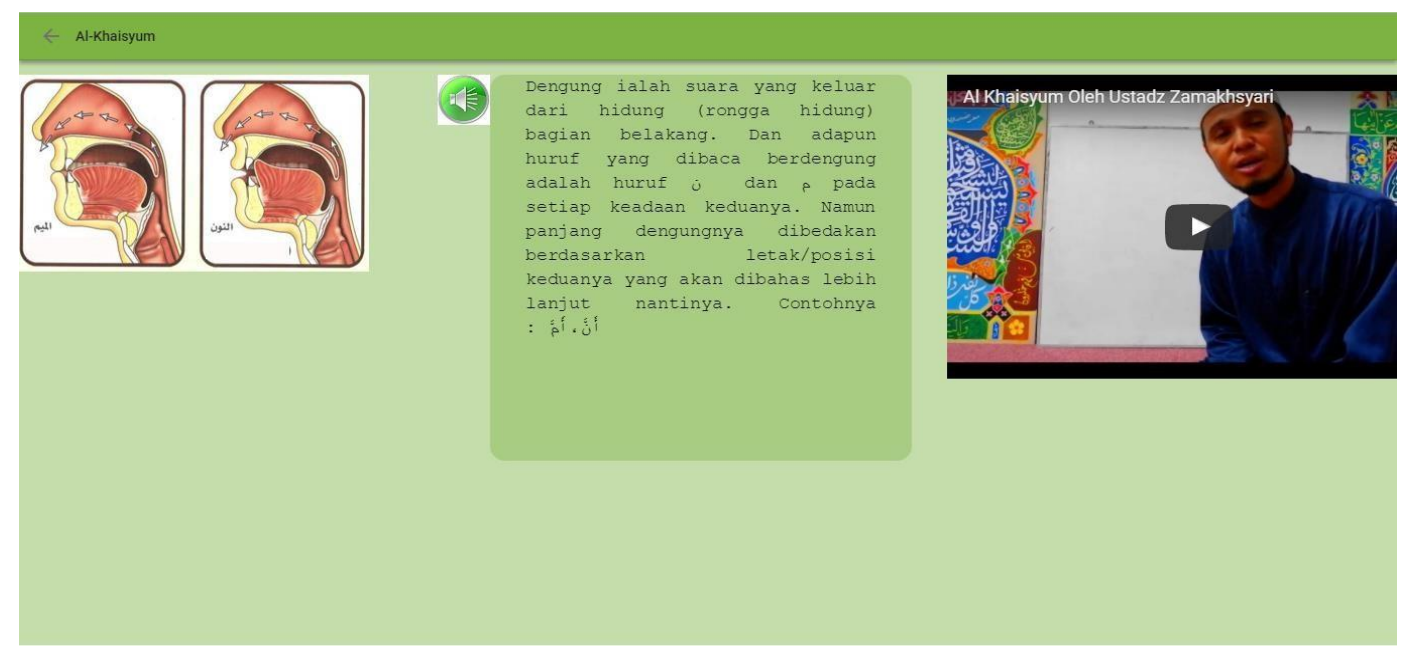

Gambar 5. Tampilan Contoh Halaman Materi Pembelajaran

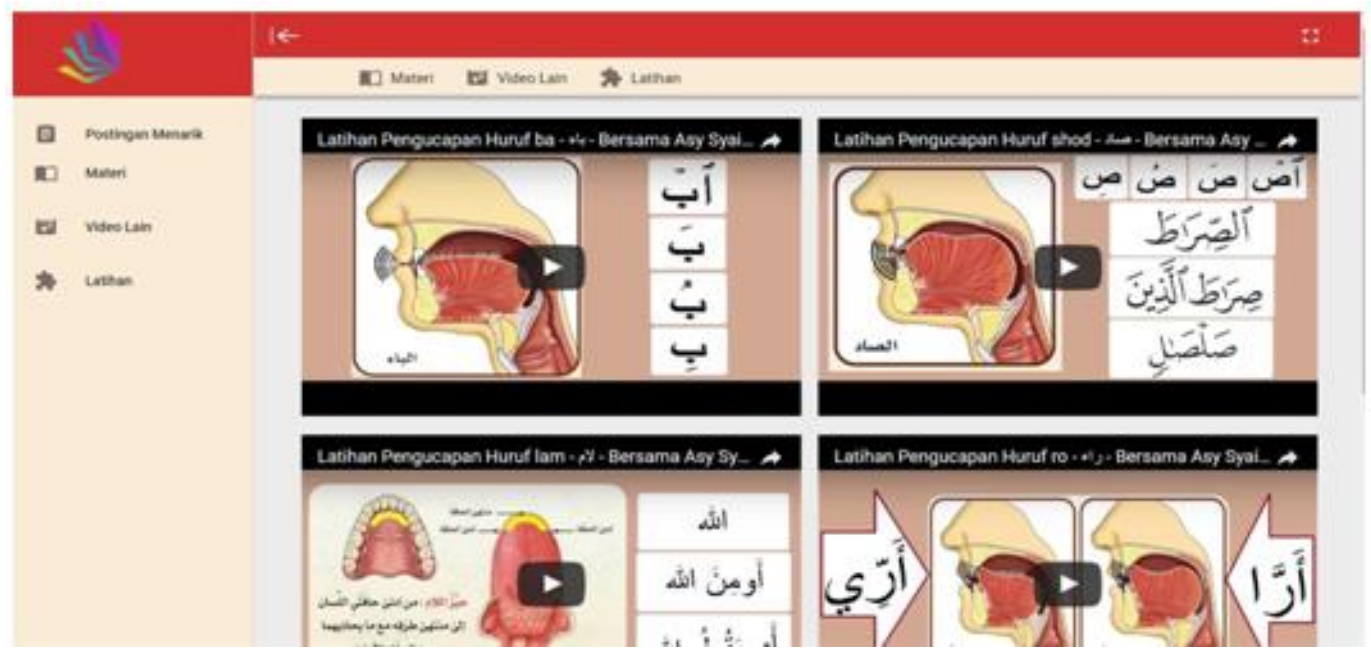

Gambar 6. Contoh Tampilan Menu Video Lain

Menu Latihan dapat diikuti oleh pengguna apabila telah melakukan login. Jika pengguna belum memiliki akun, maka pengguna dapat membuat akun terlebih dahulu yang konfirmasinya akan dikirim ke alamat email pengguna. Sesudah melakukan login, maka akan ada tambahan menu Profil pengguna. Menu ini berisi informasi-informasi dalam basis data sesuai inputan pengguna pada saat membuat akun. Selanjutnya, pengguna akan berada pada halaman kategori soal-soal. Terdapat kategori tambahan yaitu kategori "Campuran" yaitu kategori latihan yang berisi soal-soal seluruh kategori yang disajikan secara acak. Gambar 7 memperlihatkan tampilan halaman latihan_soal.

Setelah pengguna menjawab seluruh pertanyaan yang ada pada halaman Latihan, maka pengguna akan mengetahui total nilai yang diperoleh dan nilai- nilai yang pernah diikuti sebelumnya berdasarkan kategori pembelajaran dan waktu pengerjaan soal. Contoh tampilan informasi tersebut dapat dilihat pada Gambar 8. 


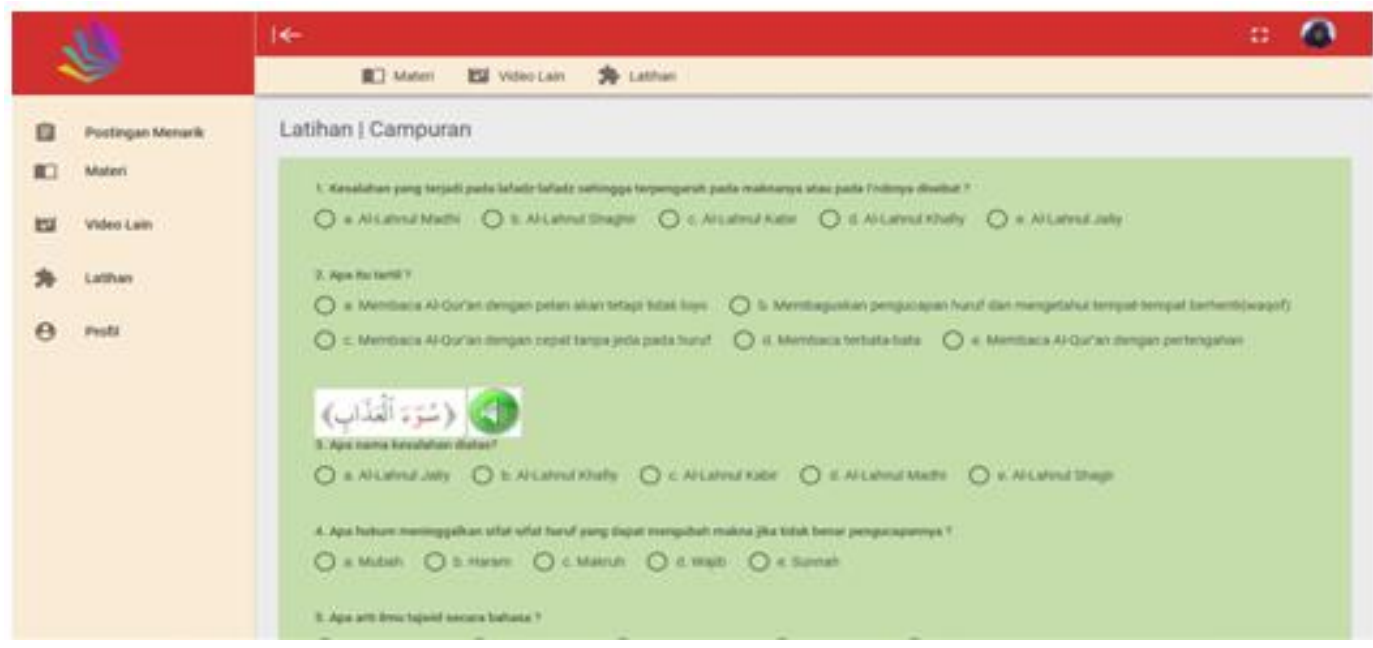

Gambar 7. Contoh Tampilan Halaman Latihan

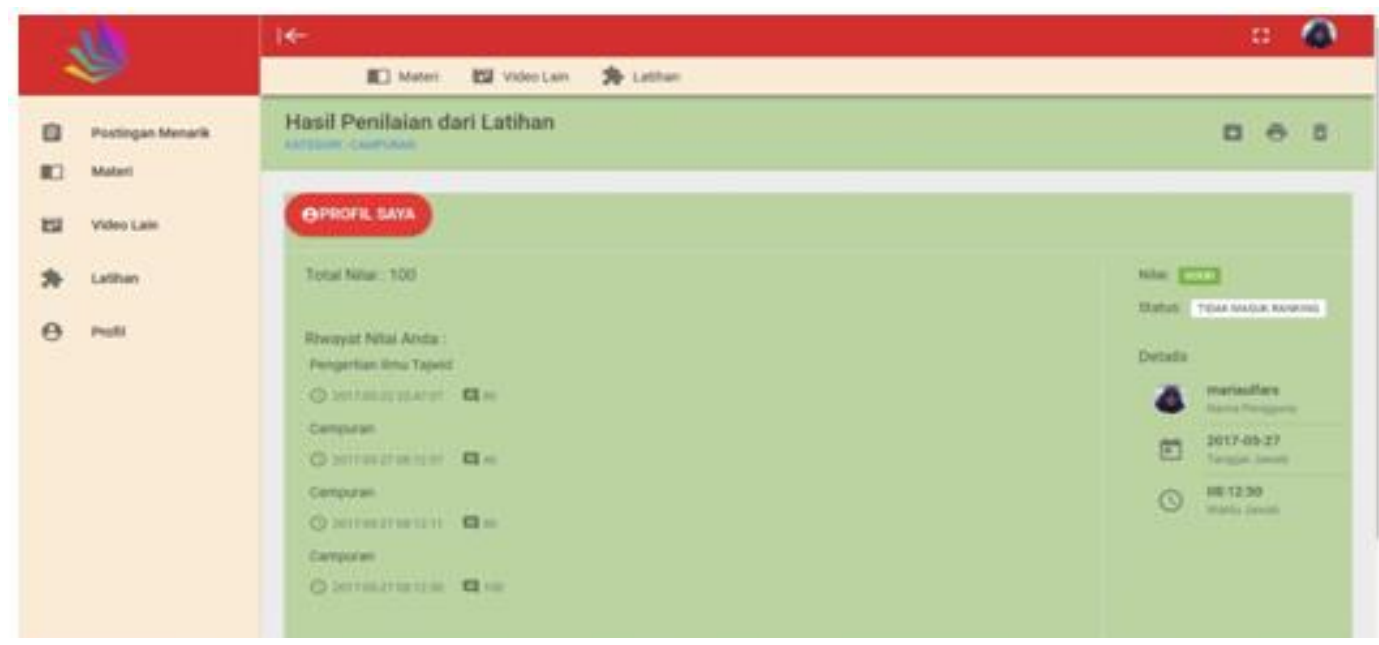

Gambar 8. Contoh Tampilan Hasil Penilaian dari Latihan

Aktor aplikasi yang lainnya adalah administrator. Administrator terlebih dahulu perlu melakukan login untuk masuk ke halaman administrator. Administrator memiliki hak untuk melakukan aksi menambahkan, menghapus dan mengubah (CRUD / Create Update Delete) konten materi, postingan menarik, video lain dan latihan serta menambah akun admin yang lain.

Proses penambahan konten postingan menarik, materi, video lain, latihan, dan admin dalam bentuk pengisian form. Bagi isian berupa gambar dan audio terdapat fasilitas drag and drop. Selain itu bagi isian video, admin hanya perlu mengetikkan link url embed sesuai dengan contoh yang disediakan pada form. Tampilan form tambah materi dapat dilihat pada Gambar 9 . Form yang lain juga tidak terlalu jauh berbeda, semuanya bergantung pada isian apa yang perlu disimpan di dalam basis data. 


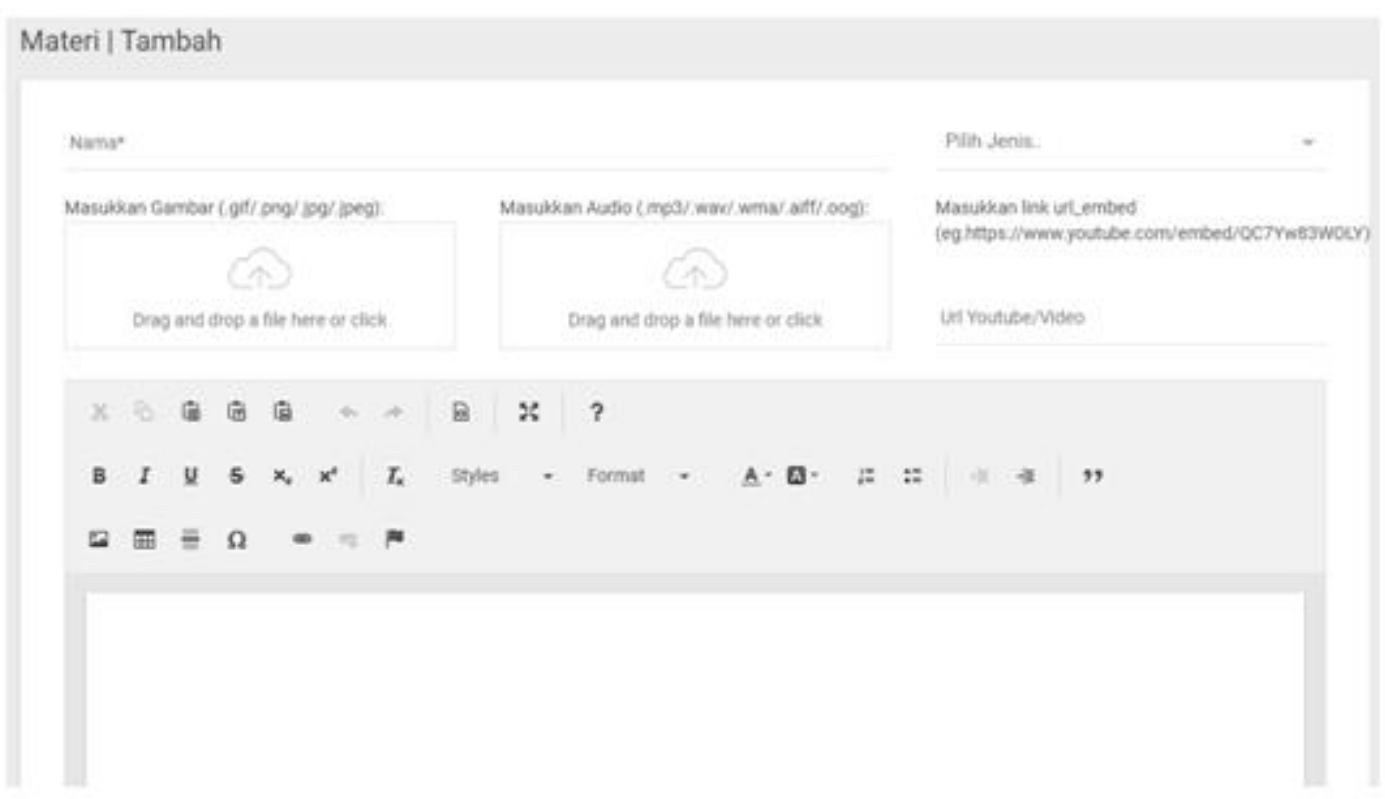

Gambar 9. Contoh Tampilan Form Tambah Materi

Prototipe aplikasi diuji dengan menggunakan metode Black Box testing. Metode Black Box testingyang digunakan disini hanya menguji fungsionalitas sistem. Hasil pengujian aplikasi ditampilkan di dalam Tabel 1 untuk aktor Pengguna dan Tabel 2 untuk aktor Administrator.

Hasil pengujian sistem yang telah ditampilkan pada tabel 1 dan 2 menunjukkan bahwa seluruh hasil pengujian bersifat valid. Hal ini berarti perancangan skenario aplikasi yang digunakan oleh pengguna dan administrator sesuai dengan rancangan dan implementasi aplikasi.

Tabel 1. Hasil Pengujian Aplikasi untuk Aktor Pengguna

\begin{tabular}{|c|c|c|c|c|}
\hline No & Pengujian & Skenario & Keluaran & Hasil \\
\hline 1 & $\begin{array}{l}\text { Pemilihan menu } \\
\text { postingan } \\
\text { menarik }\end{array}$ & $\begin{array}{l}\text { Pengguna memilih salah satu postingan } \\
\text { menarik }\end{array}$ & $\begin{array}{l}\text { Tampil postingan menarik sesuai dengan } \\
\text { yang dipilih }\end{array}$ & Valid \\
\hline \multirow[t]{2}{*}{2} & $\begin{array}{l}\text { Pemilihan menu } \\
\text { materi }\end{array}$ & $\begin{array}{l}\text { Pengguna memilih salah satu } \\
\text { materi_sub_kategori }\end{array}$ & $\begin{array}{l}\text { Tampil materi_sub_kategori sesuai dengan } \\
\text { yang dipilih }\end{array}$ & Valid \\
\hline & & $\begin{array}{l}\text { Pengguna memilih } \\
\text { materi_sub_sub_kategori }\end{array}$ & $\begin{array}{l}\text { Tampil materi_sub_sub_kategori sesuai } \\
\text { dengan yang } \\
\text { dipilih }\end{array}$ & Valid \\
\hline 3 & Memutar audio & $\begin{array}{l}\text { Pengguna meng-klik gambar icon audio di } \\
\text { salah satu materi pembelajaran dan } \\
\text { mendengarnya sampai habis }\end{array}$ & $\begin{array}{l}\text { Audio terdengar dengan baik dan sesuai } \\
\text { dengan materi pembelajaran yang dipilih }\end{array}$ & Valid \\
\hline 4 & $\begin{array}{l}\text { Menampilkan } \\
\text { video }\end{array}$ & $\begin{array}{l}\text { Pengguna memilih tombol play pada video } \\
\text { dan menonton video sampai selesai }\end{array}$ & $\begin{array}{l}\text { Video berjalan dengan baik dan sesuai } \\
\text { dengan materi pembelajaran yang dipilih }\end{array}$ & Valid \\
\hline \multirow[t]{6}{*}{5} & $\begin{array}{l}\text { Pemilihan menu } \\
\text { latihan }\end{array}$ & $\begin{array}{l}\text { Pengguna membuat akun baru dengan } \\
\text { mengisi formyang telah disediakan }\end{array}$ & $\begin{array}{l}\text { Username dan password dikirim ke email } \\
\text { pengguna dan berhasil masuk ke database }\end{array}$ & Valid \\
\hline & & $\begin{array}{l}\text { Pengguna mengosongkan salah satu } \\
\text { kolom pada form buat akun }\end{array}$ & $\begin{array}{l}\text { Terdapat pemberitahuan bahwa kolom } \\
\text { wajib diisi }\end{array}$ & Valid \\
\hline & & $\begin{array}{l}\text { Pengguna mengisi username atau email } \\
\text { yang sudah ada sebelumnya di basis data }\end{array}$ & $\begin{array}{l}\text { Muncul pemberitahuan bahwa email dan } \\
\text { atau usernameitu sudah pernah digunakan }\end{array}$ & Valid \\
\hline & & $\begin{array}{l}\text { Pengguna login dengan username dan } \\
\text { password yang telah dibuat sebelumnya }\end{array}$ & Pengguna berhasil masuk ke menu latihan & Valid \\
\hline & & $\begin{array}{l}\text { Pengguna login dengan username dan } \\
\text { password yang salah/tidak sesuai atau } \\
\text { dikosongkan }\end{array}$ & $\begin{array}{l}\text { Muncul pemberitahuan "Username dan } \\
\text { password Anda salah" }\end{array}$ & Valid \\
\hline & & $\begin{array}{l}\text { Pengguna memilih salah satu materi } \\
\text { latihan }\end{array}$ & $\begin{array}{l}\text { Tampil soal latihan berdasarkan materi } \\
\text { yang dipilih }\end{array}$ & \\
\hline
\end{tabular}




\begin{tabular}{|c|c|c|c|c|}
\hline & & $\begin{array}{l}\text { Pengguna mengisi soal latihan dan melihat } \\
\text { hasil latihan }\end{array}$ & $\begin{array}{l}\text { Dilakukan pengecekan jawaban benar dan } \\
\text { salah dan keluar total nilai yang sesuai dan } \\
\text { disimpan ke basis data }\end{array}$ & Valid \\
\hline & & $\begin{array}{l}\text { Pengguna tidak menjawab salah satu } \\
\text { kolom soal dan mengosongkan jawaban }\end{array}$ & $\begin{array}{l}\text { Terdapat pemberitahuan bahwa harus } \\
\text { memilih salah satu dari pilihan jawaban } \\
\text { pada soal tersebut }\end{array}$ & Valid \\
\hline & & Pengguna memilih menu keluar & $\begin{array}{l}\text { Halaman akan berpindah ke halaman } \\
\text { utama ( Halaman Postingan Menarik) }\end{array}$ & Valid \\
\hline 6 & $\begin{array}{l}\text { Penambahan } \\
\text { saran }\end{array}$ & $\begin{array}{l}\text { Pengguna mengisi semua kolom pada } \\
\text { form kotak saran dan menekan tombol } \\
\text { kirim }\end{array}$ & Data disimpan dalam basis data & Valid \\
\hline & & $\begin{array}{l}\text { Pengguna mengosongkan salah satu } \\
\text { kolom pada form kotak saran }\end{array}$ & $\begin{array}{l}\text { Terdapat pemberitahuan bahwa kolom } \\
\text { wajib diisi }\end{array}$ & Valid \\
\hline & & Tabel 2. Hasil Pengujian Aplikasi un & Aktor Administrator & \\
\hline No & Pengujian & Skenario & Keluaran & Hasil \\
\hline 1 & $\begin{array}{l}\text { Login } \\
\text { administrator }\end{array}$ & $\begin{array}{l}\text { Administrator memasukkan username } \\
\text { dan password dengan data yang benar } \\
\text { dan sesuai }\end{array}$ & Tampil halaman utama administrator & Valid \\
\hline & & $\begin{array}{l}\text { Administrator memasukkan username } \\
\text { dan password dengan data yang salah }\end{array}$ & $\begin{array}{l}\text { Muncul pemberitahuan "Username atau } \\
\text { Password Salah" }\end{array}$ & Valid \\
\hline & & $\begin{array}{l}\text { Administrator mengakses halaman } \\
\text { administrator tanpa melakukan login }\end{array}$ & $\begin{array}{l}\text { Halaman akan di-redirect ke halaman } \\
\text { login }\end{array}$ & Valid \\
\hline 2 & $\begin{array}{l}\text { Memilih menu } \\
\text { utama }\end{array}$ & $\begin{array}{l}\text { Administrator memilih menu Postingan } \\
\text { Menarik, Materi, Video Lain, Latihan } \\
\text { dan Saran Pengguna }\end{array}$ & $\begin{array}{l}\text { Menu Postingan Menarik, Materi, Video } \\
\text { Lain ditampilkan dalam bentuk tabel } \\
\text { sedangkan menu Latihan dan Video Lain } \\
\text { dalam bentuk dikelompokkan sesuai } \\
\text { materi kategori }\end{array}$ & Valid \\
\hline 3 & $\begin{array}{l}\text { Memilih menu } \\
\text { cari }\end{array}$ & $\begin{array}{l}\text { Administrator mencari salah satu judul } \\
\text { postingan menarik, } \\
\text { materi_sub_kategori, } \\
\text { materi_sub_sub_kategori, dan saran } \\
\text { dengan mengetik keyword di papan cari }\end{array}$ & $\begin{array}{l}\text { Tampil judul postingan menarik, } \\
\text { materi_sub_kategori, } \\
\text { materi_sub_sub_kategori, dan saran } \\
\text { yang sesuai dengan keyword jika ada } \\
\text { dalam basis data }\end{array}$ & Valid \\
\hline 4 & $\begin{array}{l}\text { Memilih menu } \\
\text { tambah }\end{array}$ & $\begin{array}{l}\text { Administrator memilih menu tambah } \\
\text { pada postingan menarik, materi, video } \\
\text { lain dan latihan }\end{array}$ & $\begin{array}{l}\text { Tampil form tambah postingan menarik, } \\
\text { materi, video lain dan latihan }\end{array}$ & Valid \\
\hline & & $\begin{array}{l}\text { Administrator tidak mengisi semua } \\
\text { kolom pada form }\end{array}$ & Muncul pemberitahuan kolom harus diisi & Valid \\
\hline & & $\begin{array}{l}\text { Administrator mengisi semua kolom } \\
\text { pada form }\end{array}$ & $\begin{array}{l}\text { Muncul pemberitahuan konten berhasil } \\
\text { ditambahkan }\end{array}$ & Valid \\
\hline 5 & $\begin{array}{l}\text { Memilih menu } \\
\text { edit }\end{array}$ & $\begin{array}{l}\text { Administrator memilih menu edit pada } \\
\text { postingan menarik, materi, video lain } \\
\text { dan latihan }\end{array}$ & $\begin{array}{l}\text { Tampil form edit postingan menarik, } \\
\text { materi, video lain dan latihan }\end{array}$ & Valid \\
\hline & & $\begin{array}{l}\text { Administrator memilih kolom yang } \\
\text { diedit }\end{array}$ & $\begin{array}{l}\text { Tampil form yang berisi data pada kolom } \\
\text { yang diedit }\end{array}$ & Valid \\
\hline & & $\begin{array}{l}\text { Administrator Menghapus isi form edit } \\
\text { yang ditampilkan dan menekan tombol } \\
\text { SUBMIT }\end{array}$ & Muncul pemberitahuan data harus diisi & Valid \\
\hline & & $\begin{array}{l}\text { Administrator mengisi perubahan data } \\
\text { pada form edit yang ditampilkan }\end{array}$ & $\begin{array}{l}\text { Isi basis data berubah dan data yang } \\
\text { ditampilkan pada form edit berubah } \\
\text { menjadi dengan data yang baru } \\
\text { dimasukkan }\end{array}$ & Valid \\
\hline 6 & $\begin{array}{l}\text { Memilih menu } \\
\text { hapus }\end{array}$ & $\begin{array}{l}\text { Administrator memilih menu hapus } \\
\text { pada postingan menarik, materi, video } \\
\text { lain, latihan, dan saran pengguna }\end{array}$ & $\begin{array}{l}\text { Halaman tetap ada namun data akan } \\
\text { terhapus di basis data sesuai dengan } \\
\text { yang dipilih dan tidak ditampilkan lagi }\end{array}$ & Valid \\
\hline
\end{tabular}




\begin{tabular}{|c|c|c|c|c|}
\hline 7 & $\begin{array}{l}\text { Memilih menu } \\
\text { Tambah }\end{array}$ & $\begin{array}{l}\text { Administrator memilih menu tambah } \\
\text { admin }\end{array}$ & Tampil form tambah administrator & Valid \\
\hline & Admin & $\begin{array}{l}\text { Administrator menambahkan data } \\
\text { administrator yang baru }\end{array}$ & $\begin{array}{l}\text { Administrator yang baru berhasil } \\
\text { ditambahkan di basis data dan dikirim } \\
\text { kan username dan }\end{array}$ & Valid \\
\hline
\end{tabular}

\section{KESIMPULAN}

IImu tajwid merupakan ilmu yang penting dipelajari oleh umat Islam. Oleh karena itu penelitian ini menghasilkan aplikasi pembelajaran ilmu tajwid yang diberi nama KepoTajwid. Pengembangan aplikasi menggunakan metode RAD yang terdiri dari tiga tahapan yaitu perencanaan kebutuhan, perancangan dan implementasi. Aplikasi ini terdiri dari dua aktor utama yaitu pengguna dan administrator. Pengguna dapat mengakses materi dengan membaca penjelasan materi, memutar audio, melihat video dan mengerjakan latihan. Pada aplikasi KepoTajwid ini terdapat 90 gambar, 50 audio dan 7 video. Materi yang disampaikan adalah materi dasar ilmu tajwid yaitu hukum nun sukun dan tanwin, hukum mim sukun, makharijul huruf, dan shifatul huruf. Pengguna juga dapat melihat postingan seputar agama Islam dan juga melihat video lain yang berkaitan dengan ilmu tajwid. Administrator dapat menambah, mengubah dan menghapus konten materi dan soal latihan. Selain itu administrator juga dapat mengelola postingan pada halaman utama, video ilmu tajwid, saran pembaca dan useradmin.

Aplikasi KepoTajwid diuji dengan menggunakan metode Black Box testing. Metode ini menguji fungsionalitas aplikasi baik fungsi oleh aktor pengguna maupun administrator. Hasil pengujian berdasarkan metode tersebut menunjukkan seluruh skenario pengujian bersifat valid. Bermakna skenario aktor pengguna dan administrator sesuai dengan rancangan dan implementasi aplikasi.

\section{DAFTAR PUSTAKA}

[1] K. El-Mahfani, Belajar Cepat IImu Tajwid: Mudah \& Praktis. WahyuQolbu, 2014.

[2] A. I. Abdurrohim, Pedoman IImu Tajwid Lengkap. Bandung: Diponegoro, 2013.

[3] D. Suryani, M. Irfan, W. Uriawan, and W. Budiawan, "Implementasi Algoritma Divide and Conquer Pada Aplikasi Belajar IImu Tajwid," J. Online Inform., vol. 1, no. 1, pp. 13-19, 2016.

[4] R. Paradesa, Z. Zulkardi, and D. Darmawijoyo, "Bahan Ajar Kalkulus 2 Menggunakan Macromedia Flash Dan Maple Di Stkip Pgri Lubuklinggau," J. Pendidik. Mat., vol. 4, no. 1, pp. 95-109, 2010.

[5] 0. Lawanto, Pembelajaran Berbasis Web Sebagai Metoda Komplemen Kegiatan Pendidikan, vol. 9. 2001.

[6] Riyanto, Membuat Sendiri Aplikasi E-commerce Dengan PHP dan MYSQL Menggunakan Codelgniter dan JQuery. Yogyakarta: Andi Publisher, 2011.

[7] A. Annuri, Panduan Tahsin Tilawah Al-Qur’an \& ilmu Tajwid, Pustaka Al. Jakarta, 2014.

[8] A. M. Ismail and M. U. Nawawi, Pedoman IImu Tajwid. Surabaya: Karya Abditama, 1995.

[9] T. Vaughan, Multimedia: Making It Work, vol. 9. McGraw Hill Professional, 2014.

[10] M. Naseer and G. Harsemadi, Sistem Multimedia. Yogyakarta: Andi Publisher, 2013.

[11] R. S. Pressman and Bruce Maxim, Software Engineering: A Practitioner's Approach, vol. 8. New York: McGraw Hill Education, 2015.

[12] K. E. Kendall and J. E. Kendall, Systems analysis and design. New Jersey: Prentice Hall, 2011.

[13] M. E. Khan, "Different forms of software testing techniques for finding errors," Int. J. Comput. Sci. Issues, vol. 7, no. 3, pp. 11-16, 2010. 